УДК 37.015.311:821:7/9(045)=111

DOI: 10.31339/2617-0833-2019-2(27)-87-90

\title{
TOPICALITY OF STUDY WORLD LITERATURE IN THE SYSTEM OF HUMANITARIAN SCIENCES
}

Hubash Diana, Rozman Iryna

\section{ТЕМАЛЬНІСТЬ ДОСЛІДЖЕННЯ СВІТОВОЇ ЛІТЕРАТУРИ В СИСТЕМІ ГУМАНІТАРНИХ НАУКИ}

Губаш Д., Розман I.I.

The article states that works of foreign literature contribute to the development of spirituality and aesthetic attitude of man to the world. The importance of the influence of the works on the formation of our own thought, the ability to perceive and comprehend the beauty of the surrounding world, to promote a better understanding of the people around us, their experiences, aspirations, hopes and hopes are highlighted. It is emphasized that without literary heritage, humanity would not have known factual information about the lives of famous people, both past and present. It is recommended to study literary masterpieces in order to form worldviews about human feelings, life and life in different historical and cultural epochs. The focus is on globalization and liberalization of Ukrainian education and its restructuring on the basis of personality-oriented pedagogy. It is stated that literature is the way to formation of non-repressive consciousness and non-conformism. literature.

Key words: actuality, works of art, specificity of teaching, cultural heritage, foreign

У статті зазначено, щуо твори зарубіжної літератури сприяють розвитку духовності та естетичному ставленні людини до світу. Виокремлено значення впливу творів на формування власної думки, вміння сприймати $і$ осягати красу навколишнього світу, сприяти кращчому розумінню оточуючих нас людей, ӥх пережсивань, прагнень, надій та сподівань. Наголошено, щчо без літературної спадщини людство не знало би фактографічні відомості життя відомих людей, як минулих часів, так і сьогодення. Рекомендовано вивчати літературні шедеври з метою формування світоглядів про людські почуття, побут та життя в різні історико-культурні епохи. Закцентована увага на глобалізації і лібералізачї украӥнської освіти й перебудови ї̈ на засадах особистісно-орієнтованої педагогіки. Зазначено, щзо література - це шлях до формування нерепресивної свідомості й нонконформізму.

Ключові слова: актуальність, художні твори, специфіка викладання, культурна спадщина, зарубіжна література.

The science of literature is connected to such humanities as history, linguistics, philosophy, logic, psychology, folklore, ethnography, art. There is a deep folk wisdom inherent in the true humanity both in the creation of values of life and in its aesthetic and moral comprehension. It is noteworthy that it was precisely the circumstance of the relation between the open and hidden semantic sense of art that Andrei Bely paid attention to. He is the one, who, as is well known, left a wide panorama of ideas about literature, creativity, and artistic directions, in addition to the versatile poetic and artistic heritage [2].

The word literature comes from the Latin "letter" - a letter. The direct meaning of this word is that it is written in letters. But later it took on a slightly different meaning: literature is something created by writers and written (or printed) on paper.

In its pragenetic premise, the evolution of the development of artistic and metaphorical worldviews, art invariably retains the element of the universal [3]. 
World Literature is so rich in literary works that one is unlikely to find a person who has not read any of works from the treasury of foreign classics in his or her lifetime. From an early age, every child is introduced to the tales of Charles Perrault, the stories of O. Henry, the sonnets of Shakespeare, Tolstoy's novels and other well-known and popular works.

With the help of literary works human is formed in various ways, whereby its inner world is enriched. The classic not only depicts an incredible palette of colors, but also teaches us life, as the works tell about the fate of people from different walks of life and different minds. Literature educates a person, improves our personality and introduces us to a mature life [4].

The main purpose of studying the subject "World Literature", in a comprehensive school is to involve students in the highest achievements of national and world literature and culture, national and universal spiritual values, the development of students' creative abilities, education in them of aesthetic taste, high readership and general culture, development of skills to become independently familiar with the samples of the art of the word, to consciously perceive the aesthetic and spiritual values embodied in them [1].

Today, as never before, the point is that people who read will always be in control of those watching television. Unfortunately, in the modern world, we are witnessing how the media can play not only a constructive but also a destructive role, using the means of black rhetoric, the total manipulation of consciousness. Therefore, the role of thoughtful critical reading is difficult to overestimate.

The functions of the development of critical thinking during reading are confirmed by analysts, scientists and writers [2].

English writer Neil Gaiman in a lecture on "Why our future depends on reading" emphasizes: "When you watch a TV show or a movie, you see things that happen to other people. Fiction is something that you create yourself with 33 letters and several punctuation marks. And only you, using your imagination, create the world, inhabit it and look around with other people's eyes. You begin to feel things, visit places and worlds that you may not know about. You realize that the outside world is you too. You become someone else, and when it is time to return to your reality, something inside you changes forever.

Literature can show you another world. It can take you to where you have never been. Once you have visited these wonderful worlds, you can never be completely satisfied with the environment in which you grew up. Dissatisfaction is a good thing. Dissatisfied people can change and improve everything around them, make the world a better place, make it different" [1].

Topical in teaching World literature is the idea of multicultural education, according to which the world literature at school is considered as a search for connections between way of thinking, peculiarities of worldview, mentality, cultural heritage of foreign countries.

Creating a cultural country context is a prerequisite for realisation of this approach. It involves the development of thoughtful and effective integration of educational subjects in the study of works of art. The study of authentic texts leads to international literary influences and borrowing, which gives birth to cultural synthesis - the basis of the formation and development of national literatures [3, p. 2-6].

The place and role of the subject "World Literature" in the system of literary education of the Ukrainian school is determined (by the materials of methodical publications) by the following factors:

1. The subject "World Literature" has great opportunities for self-awareness of Ukrainians (and not only ethnic) as citizens of a sovereign state. And much has already been done here. The subject frees our literature from the aesthetic dependence of only one, albeit truly great, literature, it introduces it into the world cultural field. This aesthetic emancipation contributes to our national self-awareness.

2. World literature, as well as Ukrainian, gives a unique opportunity to unite inhabitants of different regions of Ukraine (Shakespeare will study both Luhansk and Ternopil region), all Ukrainians - representatives of different nationalities (Cervantes will study both ethnic Ukrainian 
and Ukrainian-Crimean Tatar) and furthermore - citizens of Ukraine and other countries of the world.

3. Another time requirement is Ukraine's accession to the community of sovereign countries around the world. Mastering the spiritual, intellectual, philosophical and aesthetic potential of humanity, concentrated in the course "World Literature", will contribute to the realization of this requirement.

4. Today, more than ever, it is important from the monotony, the unitarity of thinking to move to the ability to perceive or at least listen to another point of view. This is also facilitated by the subject "World Literature", its diversity of artistic worlds, aesthetic systems, styles (for example, the French philosophical story (Voltaire "L'Ingénu”, Japanese hoku (Matsuo Basso).

5. It is also necessary to deeper, more fully "repartizate" the teaching of literature at school, to aesthetize it. Occasionalism "repartization", not the commonly used tokens "deideologization" or "depoliticization", is not accidentally used here. Formerly Dadaists (representatives of the modernist current) wrote in their manifesto: "Anyone who disagrees with this manifesto is ... a Dadaist". And so in this case: the one who calls for the lack of literature is himself engaged (opinion of O. Isayeva).

6. "Some propose to enhance the educational potential of World literature lessons,"- B. Shalaginov notes -"by abandoning the principle of science in its teaching, which is wrongly called "scientism" (scientism - "knowledge, science"- the worldview, which interprets science as a major factor in the progress of history and a means of solving social problems). Thus, the school discipline "Foreign Literature" is an important means of globalization and liberalization of Ukrainian education and its restructuring on the basis of personality-oriented pedagogy, the way to the formation of non-repressive consciousness and non-conformism [5].

Thus, a person is aware of the world versatility in the process of substantive material, spiritual-practical and spiritual-theoretical activity.

\section{Список використаних джерел}

1. Гейман Н. Чому наше майбутнє залежить від читання [Електронний ресурс]. - Режим доступу: $\quad$ http://uainfo.org/blognews/420599-chomu-nashe-maybutnye-zalezhit-vdchitannya.html.

2. Ісаєва О.О. І знову про те, чому ми вивчаємо літературу в школі [Електронний ресурс]. - Режим доступу: https://burago.com.ua/isaieva-o-o-i-znovu-pro-te-chomu-mi-vivchaie.

3. Ковбасенко Ю.І. Допоки в шкільному розкладі буде предмет «Зарубіжна література», доти школі ніхто не закине, що вона готує учнів до життя у світі, якого немає / Ю.І. Ковбасенко // Зарубіжна література. - 2005. - №5. - С. 2-6.

4. Мета вивчення зарубіжної літератури [Електронний ресурс]. - Режим доступу: http://www.educationua.net/silovs-1395-1.html.

5. Шалагінов Б.Б. Данте, Шекспір, Вольтер, Гете, Толстой «панують над умами мільонів людей, які за все своє життя не прочитали жодного рядка 3 їхніх творів» / Б.Б. Шалагінов // Всесвітня література в середніх навчальних закладах України. -1999. - № 7. - C. $8-11$.

\section{References}

1. Heyman, N. Chomu nashe maybutnye zalezhyt' vid chytannya [Why our future depends on reading]. [online] Available at: http://uainfo.org/blognews/420599-chomu-nashe-maybutnyezalezhit-vd-chitannya.html.

2. Isayeva, O.O. I znovu pro te, chomu my vyvchayemo literaturu v shkoli [And again about why we study literature at school]. [online] Available at: https://burago.com.ua/isaieva-o-oi-znovu-pro-te-chomu-mi-vivchaie.

3. Kovbasenko, Yu.I., 2005. Dopoky v shkil'nomu rozkladi bude predmet «Zarubizhna literatura», doty shkoli nikhto ne zakyne, shcho vona hotuye uchniv do zhyttya u sviti, 
yakoho nemaye [As long as there is a subject " World Literature" in the school schedule, no one will tell the school that it is preparing students for life in a world that is not there]. World Literature, 5, pp. 2-6.

4. Meta vyvchennya zarubizhnoyi literatury [Purpose of studying world literature] [online] Available at: http://www.educationua.net/silovs-1395-1.html.

5. Shalahinov, B.B. 1999. Dante, Shekspir, Vol'ter, Hete, Tolstoy «panuyut' nad umamy mil'oniv lyudey, yaki za vse svoye zhyttya ne prochytaly zhodnoho ryadka z yikhnikh tvoriv» [Dante, Shakespeare, Voltaire, Goethe, Tolstoy "rule over the minds of millions who have not read a single line of their works in their entire lives"]. World literature in secondary schools in Ukraine, 7, pp. 8-11.

УДК 37.091.313:[821+811.111](045)

DOI: 10.31339/2617-0833-2019-2(27)-90-94

\section{FEATURES OF AN INTEGRATED LESSON OF FOREIGN LITERATURE AND ENGLISH LANGUAGE}

Deshko Mariia-Khrystyna, Rozman Iryna

\section{ОСОБЛИВОСТІ ІНТЕГРОВАНОГО УРОКУ ІНОЗЕМНОЇ ЛІТЕРАТУРИ ТА АНГЛІЙСЬКОї МОВИ}

Дешко M.-X., Розман I.I.

У статті наголошено на необхідності теоретичного обтрунтування особливостей інтегрованого уроку зарубіжної літератури та англійської мови.

Закцентована увага на проблемі інтеграџії загалом та інтегрованого навчання зокрема. Розглянуто питання щуодо постійного оновлення і розвитку освітнього процесу. Зазначено, щзо форми інтегрованих уроків мають свої особливості; всі вони мають багато відмінностей, але, також, всіх їх об'єднує така спільна риса, як: ефективність розподілу часу, виділеного на опрацювання та засвоєння навчального матеріалу, а також стимулювання глобального мислення замість замкнутого та вузькоспеціалізованого. Зосереджена увага на тому, щио простого читання та перекладу художнього фрагменту не достатньо для смислового аналізу та об'єктивної очінки твору учнями.

Ключові слова: інтегровані уроки, вміння співставити, навчальний прочес, набуті знання.

The article emphasizes the need for theoretical substantiation of the features of the integrated lesson of foreign literature and English.

Emphasis is placed on the problem of integration in general and integrated learning in particular. The issue of continuous updating and development of the educational process is considered. It is noted that forms of integrated lessons have their own peculiarities; they all have many differences, but they also share a common trait: the efficiency of allocating time spent on learning and learning, and stimulating global thinking instead of closed and highly specialized. The focus is that simply reading and translating a piece of art is not enough for meaningful analysis and an objective evaluation of the work by students.

Key words: integrated lessons, ability to compare, learning process, acquired knowledge.

The usual, standard presentation of educational material without cross-curricular links is a key cause of fragmented, misperception. A person loses the ability to put their theoretical knowledge into practice, to relate it to real life. Competent use of integrated lessons by the teacher in the educational process will help to improve the cognitive learning and activity of students. 